\title{
Rancang Bangun Aplikasi Appointment dan Job Progress Control Board Berbasis Android
}

\author{
Khoirun Nasikhin $^{\# 1}$, Novi Safriadi ${ }^{\# 2}$, Anggi Perwitasari ${ }^{\# 3}$

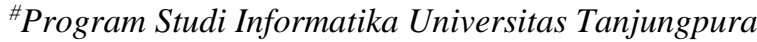 \\ ${ }^{1}$ nasikhin.k@gmail.com \\ ${ }^{2}$ safriadieinformatics.untan.ac.id \\ ${ }^{3}$ anggiperwitasarieinformatics.untan.ac.id
}

Jl. Profesor Dokter H. Hadari Nawawi, Bansir Laut, Pontianak Tenggara, Kota Pontianak, Kalimantan Barat 78115

\begin{abstract}
Abstrak - Bengkel dalam industri otomotif merupakan tempat layanan jasa perbaikan dan perawatan kendaraan. Dalam layanannya, sebuah antrian tidak bisa dihindari karena pekerjaan memerlukan waktu yang relatif lama dan diperlukan tahapan pekerjaan yang cukup banyak. Untuk mengurangi penumpukan pekerjaan, diperlukan sistem booking atau appointment sebelum hari pengerjaan. Begitu juga untuk memantau pekerjaan diperlukan juga alat job progress control board yang real time dan mudah digunakan. Tujuan yang akan dicapai dalam penelitian ini adalah menghasilkan aplikasi Appointment dan Job Progress Control Board untuk membantu pengaturan waktu antrian dan waktu pekerjaan. Menggunakan teknologi android yang memudahkan dalam hal penggunaan bisa dimana saja, dan menggunakan teknologi hybrid app untuk memudahkan pembangunan aplikasi memakai teknologi web seperti javascript, html dan css. Pengujian aplikasi dilakukan dengan black box dan pengujian operasional perangkat lunak di PT. Wahana Inti Nusa Pontianak. Pengujian operasional perangkat lunak dengan teknik User Acceptance Test mendapatkan hasil sangat baik dengan nilai 62 dari nilai semesta antara $0-70$.
\end{abstract}

Kata kunci — bengkel, antrian, booking, android, hybrid

\section{PEndahuluan}

Dalam bidang jasa dan pelayanan, menunggu adalah hal yang paling sering terjadi. Salah satu tempat pelayanan jasa yang sering terjadi antrian adalah di bengkel resmi perbaikan dan perawatan mobil. PT. Wahana Inti Nusa Pontianak adalah salah satu dealer resmi Nissan-Datsun di Kalimantan Barat yang melayani penjualan dan perawatan serta perbaikan mobil. Jenis antrian pada bengkel adalah model Multi Channel Multi Phase yaitu yang memiliki ciri dua atau lebih individu dapat dilayani pada waktu bersamaan dan memiliki tahapan pelayanan lebih dari satu.

Masalah pada bengkel yang sering terjadi adalah penumpukan antrian, dan juga ketika teknisi selesai mengerjakan kendaraan maupun terjadi masalah pada pengerjaannya, informasi tidak langsung diketahui oleh konsumen.

Penggunaan perangkat seluler yang semakin berkembang khususnya sistem operasi android bisa sangat membantu penggunanya. Dari sisi konsumen yang dapat melakukan booking lebih praktis, dan di sisi bengkel yang dapat membantu proses pekerjaan.

Penelitian ini bertujuan menghasilkan aplikasi Appointment dan Job Progress Control Board pada PT. Wahana Inti Nusa Pontianak untuk membantu pengaturan waktu antrian dan waktu pekerjaan.

\section{TINJAUAN PUSTAKA}

\section{A. Kajian Terkait}

Pada tabel berikut menggambarkan kajian terkait yang telah dilakukan dengan yang akan dilakukan.

TABEL I

PENELITIAN TERKAIT

\begin{tabular}{|l|l|l|l|}
\hline No & Penulis & \multicolumn{1}{|c|}{ Judul } & \multicolumn{1}{|c|}{ Kesimpulan Penelitian } \\
\hline 1. & Steven & $\begin{array}{l}\text { Perancangan Sistem } \\
\text { Informasi Pemesanan } \\
\text { Servis Mobil di PT. } \\
\text { Isuindomas Putra Berbasis } \\
\text { Web[1] }\end{array}$ & $\begin{array}{l}\text { Penulis membuat aplikasi } \\
\text { pemesanan servis mobil Isuzu } \\
\text { berbasis web menggunakan } \\
\text { Adobe Dreamweaver dengan } \\
\text { bahasa pemrograman PHP }\end{array}$ \\
\hline 2. & $\begin{array}{l}\text { Ryan } \\
\text { Herman } \\
\text { Ludwig } \\
\text { Tuelah } \\
\text { Bundt }\end{array}$ & $\begin{array}{l}\text { Perancangan dan } \\
\text { Implementasi Sistem } \\
\text { Informasi Service } \\
\text { Kendaraan Roda Dua di } \\
\text { Bengkel AHASS Dipo Jaya } \\
\text { Sakti[2] }\end{array}$ & $\begin{array}{l}\text { Penulis membuat aplikasi sistem } \\
\text { informasi servis kendaran roda } \\
\text { dua berbasis web yang melayani } \\
\text { dari booking sampai administrasi } \\
\text { pembayaran. }\end{array}$ \\
\hline 3. & $\begin{array}{l}\text { Khoirun } \\
\text { Nasikhin }\end{array}$ & $\begin{array}{l}\text { Rancang Bangun Aplikasi } \\
\text { Appointment dan Job } \\
\text { Progress Control Board } \\
\text { Berbasis Android }\end{array}$ & $\begin{array}{l}\text { Penulis membuat aplikasi booking } \\
\text { dan pemantauan pekerjaan servis } \\
\text { berbasis android menggunakan } \\
\text { Node.js dengan bahasa } \\
\text { pemrograman javascript }\end{array}$ \\
\hline
\end{tabular}




\section{B. PT. Wahana Inti Nusa Pontianak}

PT. Wahana Inti Nusa Pontianak adalah perusahaan otomotif dengan kegiatan usaha perdagangan besar mobil, penjualan sparepart accesories, dan bengkel mobil. Berdiri pada tanggal 26 Agustus 2002 yang beralamatkan di Jalan A.Yani II No.8B kecamatan Sungai Raya kabupaten Kubu Raya. Bergabung didalam Indomobil Group dengan penjualan produk Nissan dari PT. Nissan Motor Indonesia.

\section{Antrian}

Teori Antrian (Queuering Theory) merupakan studi matematika dari antrian atau kejadian garis tunggu (waiting lines), yakni suatu garis tunggu dari pelanggan yang memerlukan layanan dari sistem yang ada. [3]

\section{Pejadwalan}

Penjadwalan adalah aktivitas perencanaan untuk menentukan kapan dan dimana setiap operasi sebagai bagian dari pekerjaan secara keseluruhan harus dilakukan pada sumber daya yang terbatas. [4]

\section{E. Hybrid App}

Hybrid app adalah salah satu tipe mobile app yang menggunakan browser window untuk menampilkan antarmukanya. Mobile app yang berisi browser yang terisolasi, biasa disebut WebView, untuk menjalankan aplikasi web di dalam aplikasi native. Menggunakan native app wrapper yang dapat berkomunikasi dengan platform perangkat native dan WebView. Berarti aplikasi web yang dapat berjalan di perangkat seluler dan memiliki akses ke perangkat, seperti kamera atau fitur GPS.[5]

\section{F. Node.js}

Node.js dibuat oleh Ryan Dahl pada tahun 2009 menggunakan mesin javascript V8 milik Google Chrome [6]. MEAN adalah singkatan dari MongoDB, Express, AngularJS, dan Node.js. Konsep yang diusung adalah hanya menggunakan JavaScript untuk memenuhi bagian-bagian berbeda pada suatu aplikasi.[7] Dengan menggunakan Javascript dikeseluruhannya, dapat mewujudkan pencapaian kinerja yang baik dalam perangkat lunak itu sendiri maupun dalam produktivitas pengembangan.[8]

MongoDB adalah database yang tidak memiliki konsep tabel, skema, SQL, atau baris. Tidak memiliki konsep transaksi, ACID, join, foreign key.[9] MongoDB adalah database berbasis dokumen, bukan relasional.[10] Express adalah salah satu modul dari Node.js sebagai web framework untuk membangun aplikasi web dibagian server.[6] AngularJS adalah sebuah framework JavaScript pada sisi client untuk pengembangan aplikasi berbasis web. Dikembangkan secara open-source oleh Google dan komunitas programmer dan perusahaan yang berkepentingan untuk membuat aplikasi yang berjalan dalam satu halaman saja.[11]

Socket.IO adalah kombinasi dari pustaka JavaScript sisi klien dan pustaka Node.js yang digunakan untuk mengintegrasikan komunikasi dua arah antara browser dan backend Node.js. Klien dan server Socker.IO dapat berkomunikasi satu sama lain secara bidirectional.[12]

\section{G. Unified Modeling Language (UML)}

Unified modeling language adalah standarisasi pemodelan dalam pembuatan aplikasi berorientasi objek yang diajukan oleh Object Management Group pada tahun 1996.[13]

\section{PENELITIAN DAN PERANCANGAN SISTEM}

\section{A. Analisis Sistem yang Sedang Berjalan}

Adapun sistem yang sedang berjalan pada PT. Wahana Inti Nusa Pontianak adalah proses kerja yang berjalan dengan berbagai kendalanya yaitu diantaranya penerimaan booking melalui jaringan telepon yang sangat terbatas. Kendala lain adalah sistem pemantauan (monitoring) pekerjaan yang tidak berjalan dikarenakan kerumitan dalam penggunaannya, padahal sangat diperlukan untuk pengaturan waktu kerja dan informasi cepat kepada pelanggan.

\section{B. Sistem yang Akan Dibangun}

Berdasarkan analisis sistem yang sedang berjalan maka diperlukan sistem yang dapat membantu pengguna untuk mendapatkan informasi dan layanan booking lebih cepat dan mudah. Aplikasi yang mendukung kegiatan pengolahan data bengkel yang meliputi pengolahan data booking, data pekerjaan, dan data suber daya pekerja(teknisi).

1) Konsumen: Kebutuhan pengguna untuk konsumen yaitu konsumen dapat memesan waktu servis sebelum datang ke bengkel, dan melihat status pekerjaan dengan mudah.

2) $C R O$ : Kebutuhan pengguna untuk CRO yaitu dapat memasukkan konsumen booking yang tidak menggunakan aplikasi.

3) $S A$ : Kebutuhan pengguna untuk SA adalah dapat melihat konsumen yang telah melakukan booking dan menentukan waktu pekerjaan lebih tepat dengan melihat waktu pekerjaan yang telah ada. Menambahkan data pekerjaan yang siap dikerjakan baik yang sudah booking maupun yang tidak booking.

4) Foreman: Kebutuhan pengguna untuk foreman yaitu dapat melihat jumlah konsumen yang masuk lebih awal sehingga mempermudah koordinasi pekerjaan dengan teknisi. Alokasi pekerjaan dan mengubah status pekerjaan.

\section{Perancangan Arsitektur Sistem}

Perancangan arsitektur sistem yang akan dibangun adalah membuat aplikasi berbasis web dan android yang dapat diakses dengan jaringan internet. Berikut perancangan arsitektur sistem pada gambar 1 . 


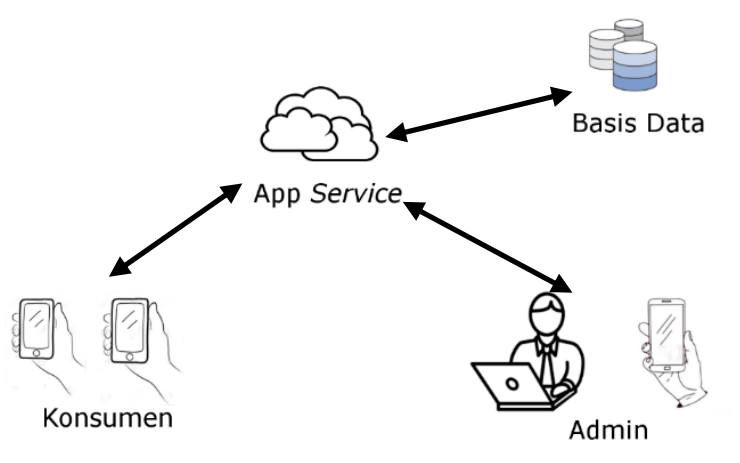

Gambar. 1 Arsitektur aliran data sistem

\section{Use Case Diagram}

Berikut adalah use case diagram yang menyatakan unit fungsi/layanan yang disediakan oleh sistem kepada pengguna pada aplikasi Appointment dan Job Progress Control Board.

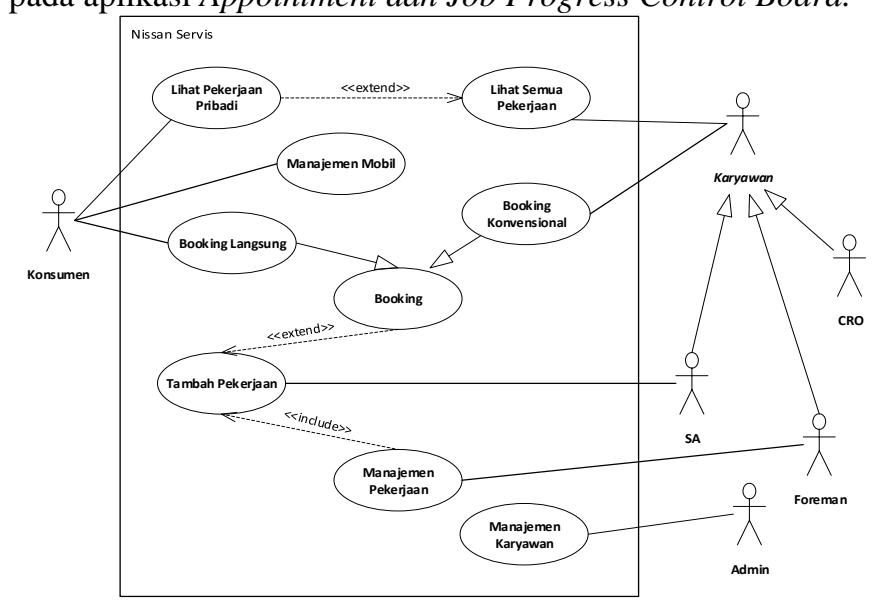

Gambar. 2 Use Case Diagram

\section{E. Activity Diagram}

Activity diagram digunakan untuk menggambarkan logika, proses bisnis dan alur kerja. Activity diagram dapat dilihat pada gambar berikut.

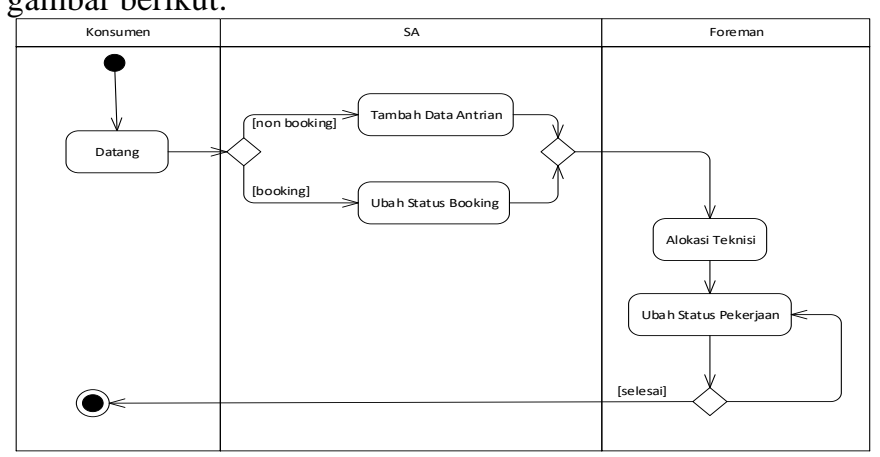

Gambar. 3 Activity Diagram

\section{F. Sequence Diagram}

Sequence diagram digunakan untuk menggambarkan skenario untuk rangkaian langkah-langkah yang dilakukan sebagai respon dari sebuah event untuk menghasilkan suatu output tertentu.

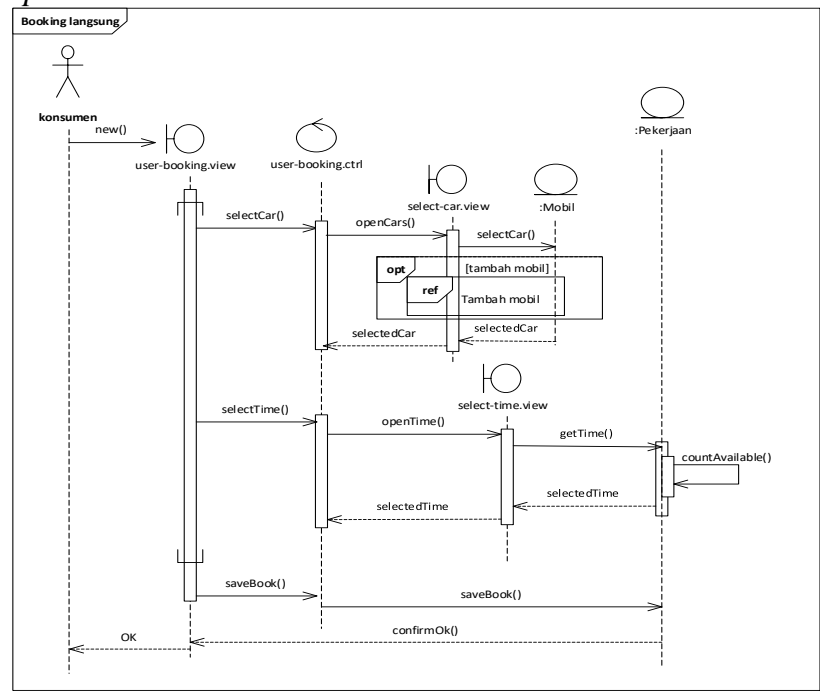

Gambar. 4 Sequence diagram booking

\section{G. Class Diagram}

Class diagram digunakan untuk menampilkan beberapa kelas yang ada dalam sistem/perangkat lunak yang akan dirancang. Class diagram dapat dilihat pada gambar berikut.

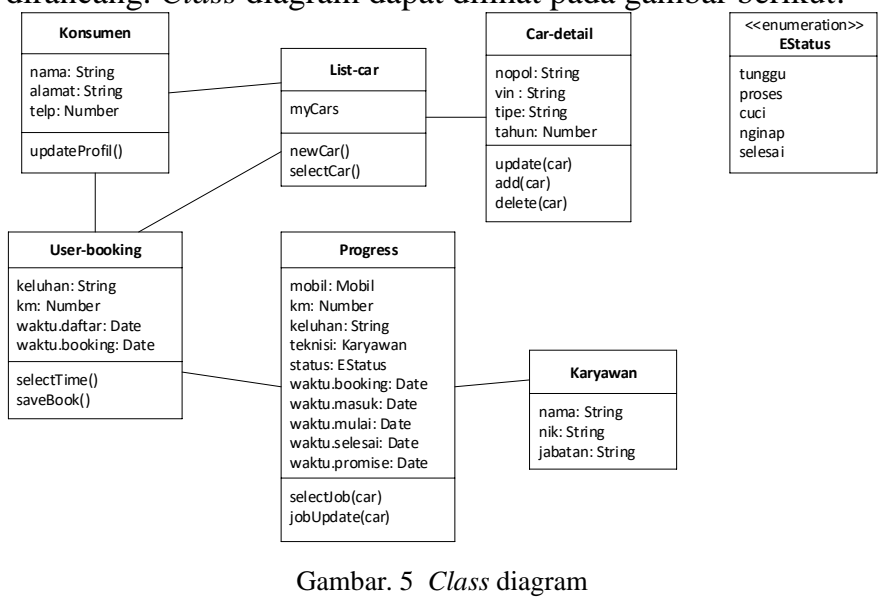

\section{IMPLEMENTASI DAN HASIL PENGUJIAN}

Pada Bab ini akan dilakukan implementasi dan hasil pengujian terhadap aplikasi. Tahapan ini dilakukan setelah perancangan sistem selesai dan selanjutnya akan diimplementasikan kemudian dilakukan pengujian terhadap aplikasi. Implementasi dan hasil pengujian yang dilakukan untuk mengetahui aplikasi tersebut dapat berjalan sesuai dengan tujuannya atau tidak 


\section{A. Implementasi}

Aplikasi yang dihasilkan adalah aplikasi berbasis web yang berjalan pada browser dan juga pada perangkat android dengan teknologi hybrid app. Dibagi menjadi dua tipe pengguna yaitu konsumen dan karyawan yang mempunyai akses berbeda.

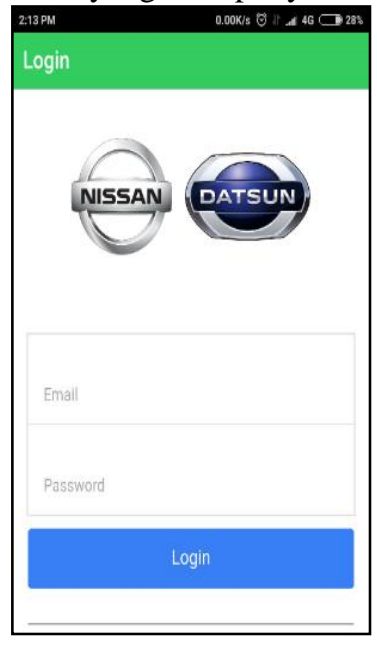

Gambar. 6 Anatarmuka halaman login

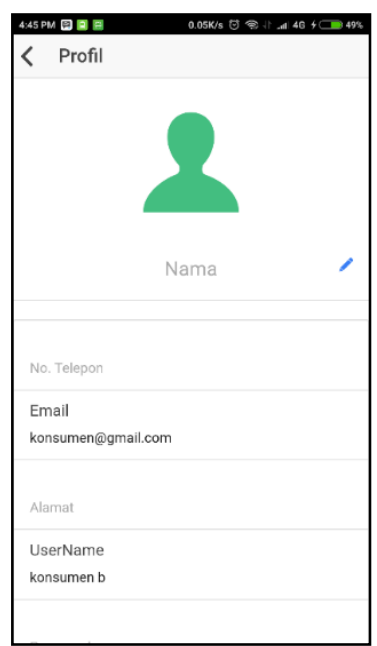

Gambar. 7 Antarmuka halaman profil

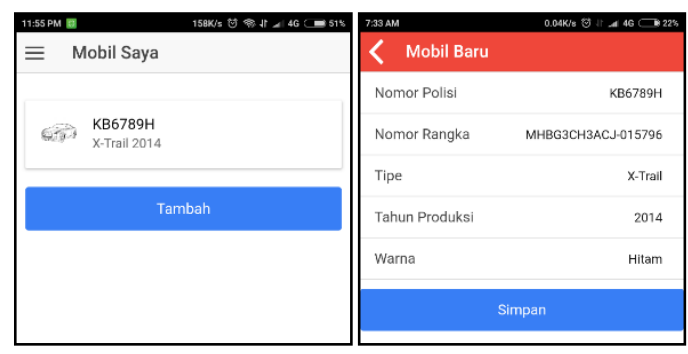

Gambar. 8 Antarmuka halaman garasi

\begin{tabular}{|c|}
\hline 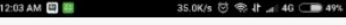 \\
\hline < Booking Service \\
\hline Pilih Mobil \\
\hline X-TRAIL KB6789H \\
\hline Jarak Tempuh \\
\hline $51,360 \mathrm{KM}$ \\
\hline Keluhan \\
\hline Berkala $50.000 \mathrm{KM}$ \\
\hline Waktu Booking \\
\hline Kamis, 18 Januari 2018 pukul 13.00 \\
\hline Booking \\
\hline
\end{tabular}

Gambar. 9 Antarmuka halaman booking konsumen

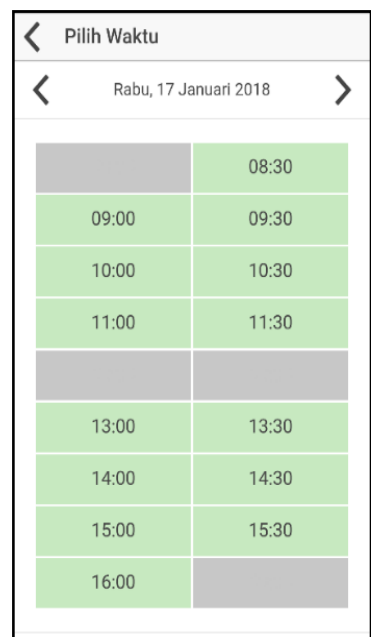

Gambar. 10 Pilih ketersediaan waktu booking

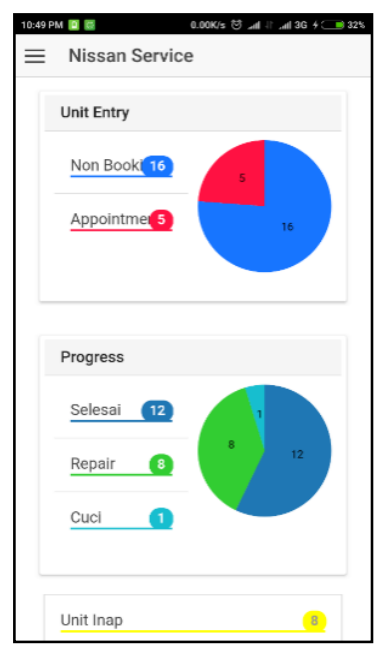

Gambar. 11 Antarmuka halaman beranda admin 


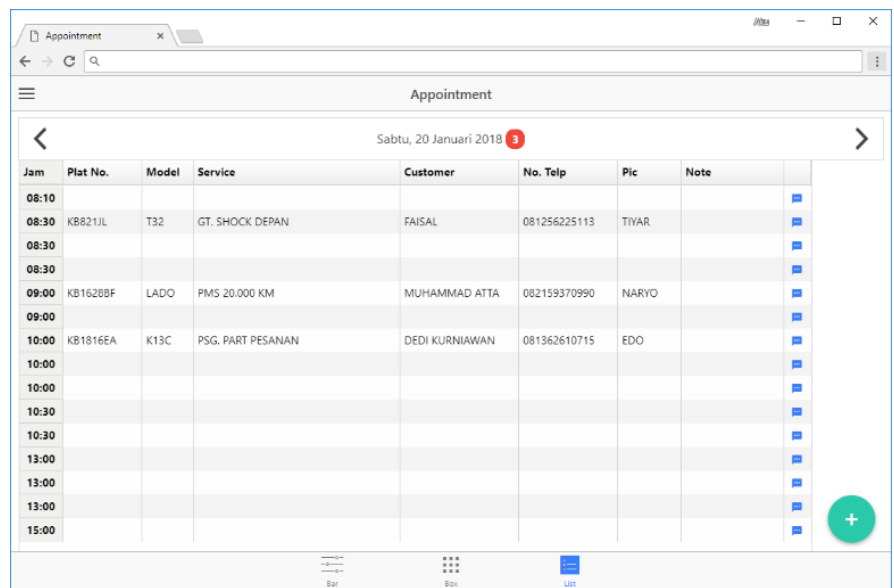

Gambar. 12 Antarmuka halaman appointment pada komputer

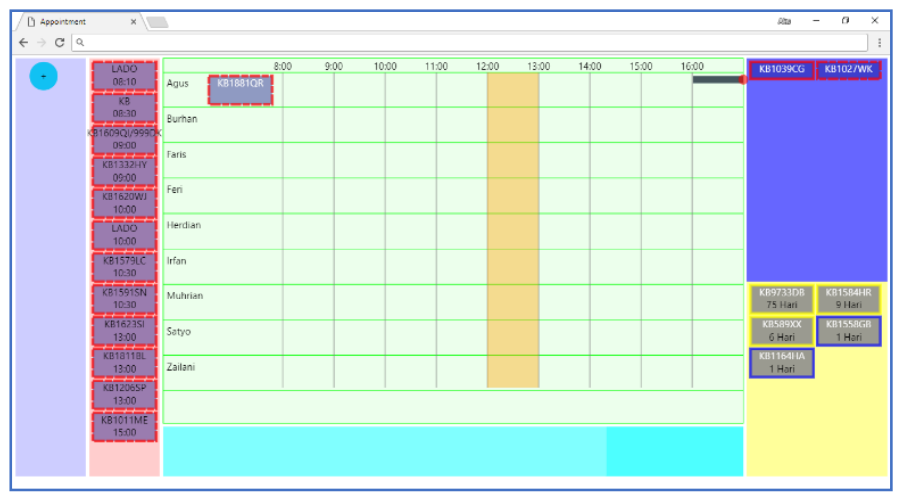

Gambar. 13 Antarmuka halaman job progress pada komputer

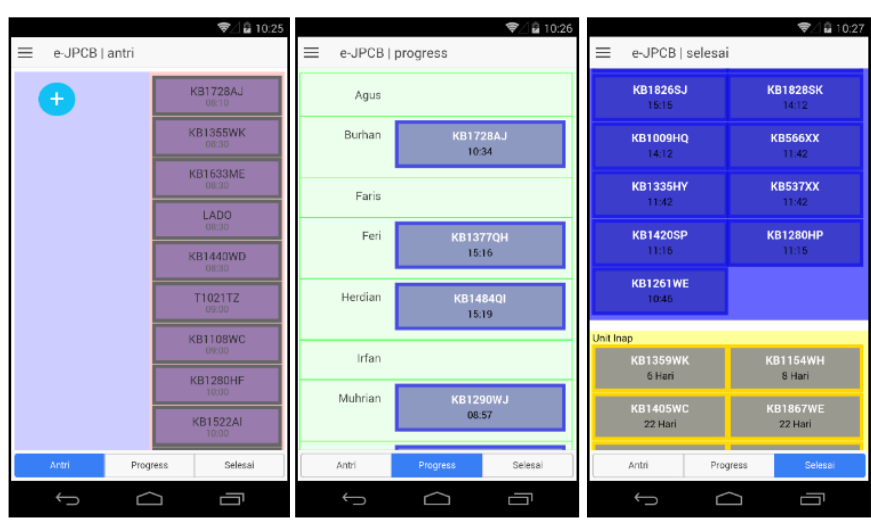

Gambar. 14 Antarmuka halaman job progress pada android

\section{B. Pengujian User Acceptance Test}

Pengujian ini dilakukan untuk melihat tingkat keberhasilan aplikasi dari pengguna terhadap operasional aplikasi. Pengujian dilakukan dengan dibagikan daftar pertanyaan tentang aplikasi kepada 15 orang responden.
TABEL III

Daftar PertanyaAn Penilaian Operasional AspeK PerangKat LunaK

\begin{tabular}{|c|l|}
\hline No & \multicolumn{1}{|c|}{ Pertanyaan } \\
\hline 1. & $\begin{array}{l}\text { Apakah tampilan informasi jadwal pekerjaan disampaikan dengan } \\
\text { jelas? }\end{array}$ \\
\hline 2. & Apakah kesesuaian warna \& font pada jadwal booking baik? \\
\hline 3. & Apakah kesesuaian warna \& font pada status pekerjaan baik? \\
\hline 4. & Apakah ukuran field isian pada tambah pekerjaan telah sesuai? \\
\hline 5. & Apakah ukuran field isian pada tambah data pemilik telah sesuai? \\
\hline 6. & Apakah ukuran field isian pada tambah detail kendaraan telah sesuai? \\
\hline 7. & Apakah pengguna dapat memahami informasi pada jadwal booking? \\
\hline 8. & Apakah pengguna dapat memahami informasi status pekerjaan? \\
\hline 9. & Apakah informasi waktu booking dapat disajikan disaat dibutuhkan? \\
\hline 10. & Apakah informasi status pekerjaan dapat disajikan disaat dibutuhkan? \\
\hline 11. & Apakah respon pada setiap perpindahan halaman lancar? \\
\hline 12. & Apakah kelancaran aplikasi stabil tanpa lag? \\
\hline 13. & Apakah waktu pekerjaan yang dihasilkan akurat? \\
\hline 14. & $\begin{array}{l}\text { Apakah status pekerjaan sesuai dengan perubahan pekerjaan oleh } \\
\text { teknisi? }\end{array}$ \\
\hline
\end{tabular}

TABEL IIIII

ReKapitulasi Penilaian OPERASiOnal AsPek Perangkat LunaK

\begin{tabular}{|c|c|c|c|c|c|c|}
\hline \multirow{2}{*}{$\begin{array}{c}\text { No. } \\
\text { Pertanyaan }\end{array}$} & \multicolumn{7}{|c|}{ Nilai Pengujian } & \multirow{2}{*}{ Total } \\
\cline { 2 - 6 } & $\mathbf{1}$ & $\mathbf{2}$ & $\mathbf{3}$ & $\mathbf{4}$ & $\mathbf{5}$ & \\
\hline 1. & 0 & 0 & 1 & 6 & 8 & 15 \\
\hline 2. & 0 & 1 & 0 & 2 & 12 & 15 \\
\hline 3. & 0 & 0 & 2 & 3 & 10 & 15 \\
\hline 4. & 0 & 1 & 0 & 8 & 6 & 15 \\
\hline 5. & 0 & 0 & 2 & 5 & 8 & 15 \\
\hline 6. & 0 & 1 & 1 & 6 & 7 & 15 \\
\hline 7. & 0 & 0 & 3 & 3 & 9 & 15 \\
\hline 8. & 0 & 1 & 1 & 5 & 8 & 15 \\
\hline 9. & 0 & 0 & 1 & 7 & 7 & 15 \\
\hline 10. & 0 & 0 & 1 & 4 & 10 & 15 \\
\hline 11. & 0 & 0 & 2 & 5 & 8 & 15 \\
\hline 12. & 0 & 0 & 1 & 6 & 8 & 15 \\
\hline 13. & 0 & 0 & 1 & 5 & 9 & 15 \\
\hline 14. & 0 & 0 & 0 & 7 & 8 & 15 \\
\hline Jumlah & $\mathbf{0}$ & $\mathbf{4}$ & $\mathbf{1 6}$ & $\mathbf{7 2}$ & $\mathbf{1 1 8}$ & \\
\hline Persentase (\%) & $\mathbf{0 \%}$ & $\mathbf{2 \%}$ & $\mathbf{8 \%}$ & $\mathbf{3 4 \%}$ & $\mathbf{5 6 \%}$ & $\mathbf{1 0 0 \%}$ \\
\hline & & & & & \\
\hline
\end{tabular}




\section{Persentase Penilaian Operasional Aspek Perangkat Lunak}

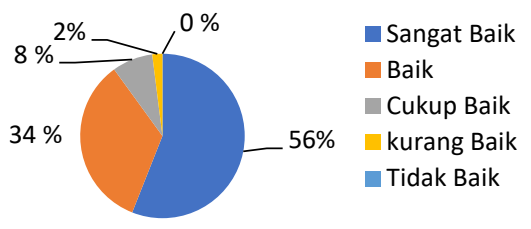

Gambar. 15 Grafik persentase penilaian perangkat lunak

TABEL IV

Hasil PenguJian OPERASIONAL APLIKASI

\begin{tabular}{|c|c|c|c|c|c|c|c|c|c|c|c|c|c|c|c|}
\hline \multirow{2}{*}{$\begin{array}{c}\text { Respo } \\
\text { nden }\end{array}$} & \multicolumn{14}{|c|}{ Hasil Penilaian } & \multirow{2}{*}{ Hasil } \\
\hline & 1 & 2 & 3 & 4 & 5 & 6 & 7 & 8 & 9 & 10 & 11 & 12 & 13 & 14 & \\
\hline 1 & 5 & 5 & 5 & 4 & 5 & 5 & 5 & 5 & 5 & 5 & 4 & 4 & 5 & 4 & 66 \\
\hline 2 & 4 & 5 & 5 & 4 & 5 & 4 & 5 & 5 & 4 & 5 & 5 & 4 & 5 & 4 & 64 \\
\hline 3 & 5 & 5 & 5 & 4 & 5 & 4 & 4 & 4 & 5 & 5 & 4 & 4 & 5 & 5 & 64 \\
\hline 4 & 4 & 5 & 5 & 5 & 4 & 4 & 5 & 4 & 4 & 5 & 3 & 4 & 4 & 5 & 61 \\
\hline 5 & 5 & 5 & 5 & 5 & 5 & 5 & 5 & 5 & 5 & 5 & 5 & 5 & 5 & 5 & 70 \\
\hline 6 & 4 & 5 & 4 & 4 & 3 & 3 & 3 & 4 & 4 & 4 & 3 & 3 & 4 & 4 & 52 \\
\hline 7 & 4 & 4 & 4 & 4 & 4 & 4 & 3 & 3 & 3 & 3 & 5 & 5 & 4 & 4 & 54 \\
\hline 8 & 4 & 5 & 3 & 4 & 4 & 4 & 4 & 4 & 4 & 4 & 5 & 5 & 4 & 4 & 58 \\
\hline 9 & 5 & 5 & 5 & 4 & 4 & 5 & 5 & 5 & 4 & 5 & 4 & 5 & 5 & 5 & 66 \\
\hline 10 & 3 & 2 & 3 & 2 & 3 & 2 & 3 & 2 & 4 & 4 & 4 & 4 & 3 & 4 & 43 \\
\hline 11 & 5 & 5 & 5 & 5 & 5 & 5 & 5 & 5 & 5 & 5 & 5 & 5 & 5 & 5 & 70 \\
\hline 12 & 5 & 5 & 5 & 5 & 5 & 5 & 5 & 5 & 5 & 5 & 5 & 5 & 5 & 5 & 70 \\
\hline 13 & 5 & 5 & 5 & 5 & 5 & 5 & 5 & 5 & 5 & 5 & 5 & 5 & 5 & 5 & 70 \\
\hline 14 & 4 & 4 & 4 & 4 & 4 & 4 & 4 & 4 & 4 & 4 & 4 & 4 & 4 & 4 & 56 \\
\hline 15 & 5 & 5 & 5 & 5 & 5 & 5 & 5 & 5 & 5 & 5 & 5 & 5 & 5 & 5 & 70 \\
\hline \multicolumn{15}{|c|}{ Jumlah } & 934 \\
\hline & & & & & & t & Has & & & & & & & & 62 \\
\hline
\end{tabular}

Pada setiap pertanyaan aspek perangkat lunak yang diajukan kepada responden, terdapat 5 opsi jawaban yang ditawarkan. Jumlah pertanyaan kuesioner yang diajukan dalam pengujian adalah 14 pertanyaan. Dengan demikian nilai hasil pengujian setiap responden sebagai berikut:

1. Nilai maksimal $=70(5 \times 14$ pertanyaan $)$

2. Nilai kuartil III $=56(4 \times 14$ pertanyaan $)$

3. Nilai median $=42(3 \times 14$ pertanyaan $)$

4. Nilai kuartil $\mathrm{I}=28(2 \times 14$ pertanyaan $)$

5. Nilai minimal $=14(1 \times 14$ pertanyaan $)$

Interpretasi nilai hasil pengujian tersebut yaitu:

1. $56-70$ aspek dinilai sangat baik

2. 42 - 55,9 aspek dinilai baik

3. $28-41,9$ aspek dinilai kurang baik

4. $14-27,9$ aspek dinilai tidak baik

Dari hasil pengujian aspek perangkat lunak didapat nilai rata-rata sebesar 62 yang diinterpretasikan maka dapat disimpulkan bahwa keseluruhan aplikasi dinilai 62 sangat baik.

\section{KESIMPULAN DAN SARAN}

Berdasarkan hasil penelitian dan pembahasan mengenai Aplikasi Appointment dan Job Progress Control Board berbasis android, maka dapat disimpulkan sebagai berikut:

- Hasil perancangan dan pembuatan aplikasi sudah dilakukan dapat membantu pekerjaan pengaturan waktu antrian dan waktu pekerjaan melalui aplikasi Appointment dan Job Progress Control Board berbasis android.

- Hasil pengujian aplikasi didapat melalui pengujian black box dan pengujian Operasional Perangkat Lunak. Berdasarkan pengujian black box telah berjalan fungsinya sesuai dengan kebutuhan fungsional.

- Berdasarkan hasil pengujian Operasional Perangkat Lunak dengan teknik User Acceptance Test pada aplikasi yang dilakukan kepada 15 orang. Hasil pengujian ini mendapatkan nilai 62 dari nilai semesta antara $0-70$ yang diinterpretasikan dengan sangat baik

Adapun hal-hal yang menjadi saran sebagai bahan pertimbangan untuk pengembangan aplikasi agar menjadi lebih baik adalah sebagai berikut:

- Aplikasi dikembangkan ke level terpusat yang dapat menangani lebih dari satu bengkel dan konsumen dapat memilih bengkel yang terdaftar.

- Penambahan fitur untuk pelayanan rekomendasi susulan dalam penggantian suku cadang

\section{REFERENSI}

[1] Steven, Perancangan Sistem Informasi Pemesanan Servis Mobil di PT. Isuindomas Putra Berbasis Web, Medan: Sekolah Tinggi Manajemen Informatika Komputer, 2015.

[2] R. H. L. T. Bundt, Perancangan dan Implementasi Sistem Informasi Service Kendaraan Roda Dua di Bengkel AHASS Dipo Jaya Sakti, Salatiga: Universitas Kristen Satya Wacana, 2016.

[3] E. Fitri, Simulasi Antrian dan Implementasinya, Medan: Universitas Sumatera Utara, 2009.

[4] E. D. Mawarti, Penjadwalan Mesin Paralel Non Identik Untuk Pembuatan Kain Grey, Yogyakarta: Universitas Atma Jaya Yogyakarta, 2009.

[5] J. Wilken, Ionic in Action, Shelter Island: Manning Publications, 2016.

[6] S. Holmes, Getting MEAN with Mongo, Express, Angular and Node, Shelter Island: Manning Publications, 2016.

[7] A. Q. Haviv, MEAN Web Development, Birmingham: Packt Publishing Ltd, 2014.

[8] V. Karpov, "MongoDB blog post | The MEAN Stack: MongoDB, ExpressJS, AngularJS and Node.js," 30 April 2013. [Online]. Available: https://www.mongodb.com/blog/post/the-mean-stackmongodb-expressjs-angularjs-and.

[9] D. Hows, E. Plugge dan P. Membrey, MongoDB Basics, New York: Apress, 2014.

[10] K. Chodorow, MongoDB The Definitive Guide, California: O'Reilly Media, Inc, 2013.

[11] R. Branas, AngularJS Essentials, Birmingham: Packt Publishing Ltd, 2014.

[12] N. Prusty, Modern JavaScript Applications, Birmingham: Packt Publishing Ltd, 2016. 
[13] M. Seidl, M. Scholz, C. Huemer and G. Kappel, UML @ Classroom: An Introduction to Object-Oriented Modeling, Switzerland: Springer International Publishing, 2015.

[14] “JEPIN (Jurnal Edukasi dan Penelitian Informatika),” 2018. [Online]. Available: http://jurnal.untan.ac.id/index.php/jepin/pages/view/ template.

[15] “JUSTIN (Jurnal Sistem dan Teknologi Informasi)," 2018.[Online]. Available: http://jurnal.untan.ac.id/index.php/justin. 